\title{
慢性腎不全児の成長発育に関する検討
}

\author{
水野愛子佐久間 進* 門脇 純一** 星 井 桜子** \\ 中 村 雄 二*** 濱口武士****喜多青三***** \\ 国立療養所中部病院小児科 同道北病院小児科* 同西札幌病院小児科 ${ }^{* *}$ 同広島病院外科*** \\ 同香川小児病院小児科 $* * * *$ 同東徳島病院外科 $* * * * *$
}

(平成 1 年 4 月 1 日受付・平成 1 年 6 月 20 日受理)

key words : 成長発育, 慢性腎不全, 血液透析, CAPD, 腎移植

〈要旨〉

国立療養所 21 施設における小児期末期腎不全患者 118 例の成長発育の実態をアンケート調査した。発症/発見時の $Z$ Zコア (mean $\pm S E)$ は, 身長 $-0.60 \pm 0.26$, 体重一 $0.46 \pm 0.18$ で, 先天性腎尿路奇形群で低值であった。 透析導 入時の Zスコアは, 身長 $-1.63 \pm 0.19$, 体重 $-1.37 \pm 0.12$ と発症/発見時より有意に低下し, 先天性腎尿路奇形・慢性 腎監堅群で低值であった。最終観察時の Zスコアは, 身長 $-2.16 \pm 0.21$, 体重 $-1.73 \pm 0.11$ とさらに低下し, 先天 性腎尿路奇形・慢性腎孟腎炎・一次性系球体腎炎群で低い傾向があった。導入後の治療法 (HD, CAPD, 腎移植) によ る成長発育状態の差異は認められず，どの治療法によっても経過とともに Zスコアの悪化傾向を認めた。 Zスコアの 改善例は, 導入時発育の高度遅延例が多く, 増悪例は軽度のものが多かった. 15 歳以上の女子 19 例中初潮がない 4 例 は, 身体発育高度遅延例が多かった。

\section{Growth and sexual maturation in children with end-stage renal failure}

Aiko Mizuno, M. D., Susumu Sakuma, M. D.*, Junichi Kadowaki, M. D.**, Sakurako Hoshii, M. D.**, Yuji Nakamura, M. D. ${ }^{* * *}$, Takeshi Hamaguchi, M. D. ${ }^{* * *}$, Seizo Kita, M. D. ${ }^{* * * *}$

Department of Pediatrics, National Chubu Hospital ; National Dohoku Hospital* ; National Nishi-Sapporo Hospital $^{* *}$; National Hiroshima Hospital*** ; National Kagawa Children's Hospital ${ }^{* * * *}$; National HigashiTokushima Hospital ${ }^{* * * *}$

Growth and sexual maturation in 118 children with end-stage renal failure were investigated through questionaires in 21 national sanatoriums. At disease onset and/or detection, the $\mathrm{Z}$ scores of body height $(\mathrm{BH})$ and body weight (BW) (mean $\pm \mathrm{SE}$ ) were $-0.60 \pm 0.26$ and $-0.46 \pm 0.18$ respectively. The scores were comparatively lower in patients with congenital renal/urinary tract anomaly. At the beginning of dialysis, $Z$ scores decreased significantly to $-1.63 \pm 0.19(\mathrm{BH})$ and $-1.37 \pm 0.12(\mathrm{BW})$, and those in patients with congenital anomaly or pyelonephritis were lower than those in others. At the final check-up, $Z$ scores decreased further to $-2.16 \pm 0.21(\mathrm{BH})$ and $-1.73 \pm 0.11$ (BW) and were lower in those with congenital anomalies, pyelonephritis or primary glomerulonephritis. There was no significant difference in growth according to the kind of treatment (HD, CAPD or transplantation) ; all treatments were associated with progressive decreasing $Z$ scores. Most of the cases with improved $Z$ scores had presented severe growth retardation at the beginning of dialysis, while those with worsening $Z$ scores showed slight retardation. Of 19 girls above 15 years old, four had no menarche and showed severe growth retardation.

はじめに

小児期慢性腎不全患者の合併症のうち，成長発育障害 は主要なものの一つであり, その実態を把握して, 適切

水野 愛子 国立療養所中部病院小児科

₹ 474 大府市森岡町源吾 36-3 (0562-46-2311)
な治療管理を行うことは，意義のあることと思われる．

今回, 国立療養所における末期腎不全児の成長発育の 実態についてアンケート調查を行って, 原疾患との関 係・病期による変化・治療法による差異について検討し た。 
表 1 研究参加施設, 回答者および患者数

\begin{tabular}{|c|c|}
\hline 研究参加施設 & 患者数 \\
\hline 国立療養所道 北 病 院：佐久間進 & 1 \\
\hline 西 札 幌 病 院: 門脇純一, 菅原宏見, 星井桜子 & 40 \\
\hline 岩 木 病 院：黒沼忠由紀 & 3 \\
\hline 山 形 病 院：佐藤千香子 & 2 \\
\hline 西多賀病院：古山美智子 & 11 \\
\hline 福 島 病 院：藤野純子, 仁保幸次 & 1 \\
\hline 千葉 東病院：倉山英昭 & 7 \\
\hline 神奈川病 院：榊原達郎 & 1 \\
\hline 医 王 病 院: 本家一也 & 1 \\
\hline 東松本病院：森 哲夫 & 3 \\
\hline 長 良 病 院：山田重昭 & 1 \\
\hline 中 部 病 院：水野愛子 & 19 \\
\hline 三 重 病 院：吉住 完, 羽根康之 & 7 \\
\hline 兵庫中央病院：溝尻素子 & 1 \\
\hline 広 島 病 院：中村雄二 & 1 \\
\hline 香 川 病 院：浜口武士 & 9 \\
\hline 東徳島病院：喜多青三 & 3 \\
\hline 西別 府病 院：古瀬昭夫 & 2 \\
\hline 福 岡 東 病 院：教正院靖子 & 1 \\
\hline 南福 岡病 院：西間三馨, 桐野良二 & 1 \\
\hline 南九州病 院：上村孝子 & 3 \\
\hline 計 & 118 \\
\hline
\end{tabular}

\section{対象と方法}

調查対象は 18 歳以下で慢性透析あるいは腎移植を受 けたか，それとほほ同等の腎機能に至った慢性腎不全患 者とし，1) 腎疾患の発症あるいは発見時 2 ) 透析導入 時 3 ) 最終観察時の三点における身長・体重をアンケー 卜調査した。アンケートは，血液透析設備あるいは小児 科を有する国立療養所の計 53 施設に送付した。

得られた各症例の值は $Z$ スコアで表し, 疾患群別・治 療法別に $Z$ スコア $(\mathrm{SD}$ スコア) を算出し, ウェルチの方 法により $\mathrm{t}$ 検定を行った。 Zスコアは, 各個人の值を昭 和 55 年度厚生省乳幼児身体発育值および昭和 55 年度学 校統計調查報告書による同年齢览の平均值 $+Z \times$ 標準偏 差として表した際の $Z$ の值であり，また $Z$ スコア年次変 化量 $(\Delta Z)$ は（最終観察時 $Z$ スコア一導入時 $Z$ スコア）/ 導入後観察年数である.

\section{結果}

27 施設から回答を得（回収率 $50.9 \%$ ), 内，上記対象 を有し調査結果を回収できたのは 21 施設であった（表 1). 総患者数は 118 例（男 69，女 49）である. 1. 原疾患

118 例の原疾患は一次性および二次性系球体疾患が 73 例 $(61.8 \%)$ と最も多く，一次性は 62 例 $(52.5 \%)$ でそ の内訳は慢性系球体腎炎 27 例, IgA 腎症 4 例, RPGN 2 例, MPGN 5 例, ネフローゼ症候群 24 例 (FGS 12, 微
表 2 小児末期腎不全 118 例の原疾患

\begin{tabular}{|c|c|c|c|c|}
\hline 群 & 原疾患 & 男 & 女 & 計(\%) \\
\hline \multirow[t]{15}{*}{1} & 系球体疾患 & 47 & 26 & $73(61.8)$ \\
\hline & A：一次性 & 44 & 18 & $62(52.5)$ \\
\hline & 慢性系球体腎炎 & 18 & 10 & $28(23.7)$ \\
\hline & IgA 腎症 & 3 & 1 & $4(3.4)$ \\
\hline & 急速進行性腎炎 & 1 & 1 & $2(1.7)$ \\
\hline & 膜性増殖性腎炎 & 3 & 1 & $4(3.4)$ \\
\hline & ネフローゼ症候群 & 19 & 5 & $24(20.4)$ \\
\hline & 微少変化群 & 1 & 0 & $1(\quad 0.8)$ \\
\hline & FGS & 9 & 3 & $12(10.2)$ \\
\hline & 腎炎性 & 4 & 2 & $6(5.1)$ \\
\hline & 不明 & 5 & 0 & $5(4.3)$ \\
\hline & B ：二次性 & 3 & 8 & $11(9.3)$ \\
\hline & 紫斑病性腎炎 & 3 & 3 & $6(5.1)$ \\
\hline & ループス腎炎 & 0 & 4 & $4(3.4)$ \\
\hline & 多発性動脈周囲炎 & 0 & 1 & $1(0.8)$ \\
\hline \multirow[t]{2}{*}{2} & 慢性腎孟腎炎 & 3 & 2 & $5(4.3)$ \\
\hline & 逆流性腎症 & 2 & 1 & $3(2.5)$ \\
\hline \multirow[t]{2}{*}{3} & 代謝性腎疾患 & & & \\
\hline & 糖原病 & 1 & 0 & $1(0.8)$ \\
\hline \multirow[t]{6}{*}{4} & 先天性腎尿路奇形 & 8 & 11 & $19(16.1)$ \\
\hline & 低形成 ～～～～～～～ & 4 & 7 & $11(9.4)$ \\
\hline & オリゴメガネフロニア & 2 & 1 & $3(2.5)$ \\
\hline & ネフロノフチジス & 0 & 2 & $2(1.7)$ \\
\hline & 囊胞性腎疾患 & 1 & 0 & $1(0.8)$ \\
\hline & 神経因性膀胱 & 1 & 1 & $2(1.7)$ \\
\hline 5 & アルポート症候群 & 7 & 3 & $10(8.5)$ \\
\hline \multirow[t]{3}{*}{6} & その他 & 0 & 2 & $2(1.7)$ \\
\hline & 急性尿細管壊死 & 0 & 1 & $1(0.8)$ \\
\hline & ウィルムス腫瘍 & 0 & 1 & $1(0.8)$ \\
\hline \multirow[t]{2}{*}{7} & 不明 & 1 & 4 & $5(4.3)$ \\
\hline & 計 & 69 & 49 & $118(100.0)$ \\
\hline
\end{tabular}

少変化群 1 , 腎炎性 6 , 不明 5 ）であり，また二次性は 11 例 (9.3\%) で，紫斑病性腎炎 6 例，ループス腎炎 4 例, 多発性動脈周囲炎 1 例であった。次に多いのは先天性腎 尿路奇形 19 例（16.1\%）で，内訳は低形成 11 例，オリ ゴメガネフロニア 3 例, ネフロノフチジス 2 例, 多発性 囊胞腎 1 例, 神経因性膀胱 2 例であった。アルポート症 候群は 10 例 $(8.5 \%)$, 慢性腎孟腎炎/逆流性腎症 8 例 $(6.8 \%)$, その他, 糖原病 1 例, 急性尿細管壊死 1 例, ウィ ルムス腫瘍 1 例があり， 5 例が不明であった（表 2 )。

\section{2. 転帰}

118 例中 116 例が透析に導入され，13 例が死亡し， 36 例が腎移植を受けた。 1987 年 8 月現在転帰の明らかな 100 例中, 透析中のものが 61 例, 移植腎で生存中のもの が 22 例, 死亡したものが 17 例である（図 1 ).

3. 発症あるいは発見時の発育と Zスコア

39 例中，身長がー2 SD 以下のものは 7 例 (17.9\%), 体重では 5 例 $(12.8 \%), 2 \mathrm{SD}$ 以上のものは身長で 1 例 


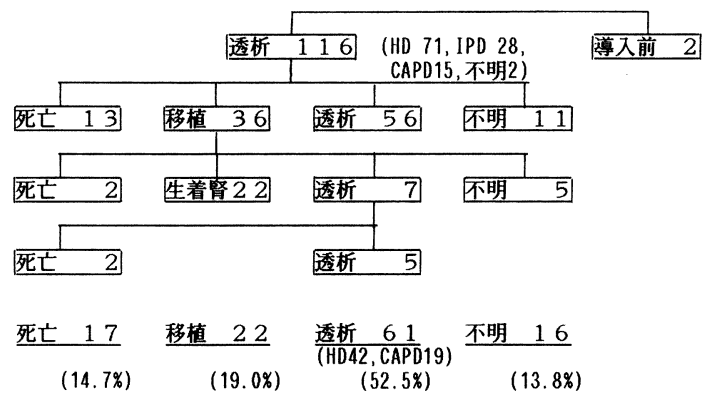

図 1 小児末期腎不全 118 例の転帰 (1972.2 1987.8)
表 3 発症/発見時の身長および体重 Zスコア

\begin{tabular}{|c|c|c|c|c|c|}
\hline & \multirow{2}{*}{ 原疾患群 } & \multicolumn{2}{|r|}{ 身 長 } & \multicolumn{2}{|r|}{ 体 重 } \\
\hline & & $\mathrm{N}$ & $\mathrm{M} \pm \mathrm{SE}$ & $\mathrm{N}$ & $\mathrm{M} \pm \mathrm{SE}$ \\
\hline \multirow[t]{4}{*}{1} & 系球体疾患 & 26 & $0.05 \pm 0.20$ & 25 & $-0.13 \pm 0.17$ \\
\hline & 一次性系球体腎炎 & 14 & $-0.01 \pm 0.29$ & 13 & $-0.23 \pm 0.27$ \\
\hline & ネフローゼ症候群 & 7 & $-0.25 \pm 0.22$ & 7 & $-0.04 \pm 0.12$ \\
\hline & 二次性系球体腎炎 & 5 & $0.63 \pm 0.58$ & 5 & $0.12 \pm 0.45$ \\
\hline 2 & 慢性腎孟腎炎 & 0 & & 0 & \\
\hline 3 & 代謝性腎疾患 & 1 & -4.57 & 1 & -2.59 \\
\hline 4 & 先天性腎尿路奇形 & 8 & $-1.97 \pm 0.50$ & 9 & $-1.10 \pm 0.39$ \\
\hline 5 & アルポート症候群 & 2 & $-0.03 \pm 0.62$ & 2 & $0.26 \pm 0.47$ \\
\hline 6 & その他 & 1 & 0.13 & 1 & 0.44 \\
\hline \multirow[t]{2}{*}{7} & 不 明 & 1 & 4.50 & 1 & -3.20 \\
\hline & 計 & 39 & $-0.60 \pm 0.26$ & 39 & $-0.46 \pm 0.18$ \\
\hline
\end{tabular}

表 4 導入時の身長および体重 Zスコア

\begin{tabular}{|c|c|c|c|c|c|c|c|c|}
\hline & \multirow{2}{*}{ 原疾患群 } & \multicolumn{2}{|r|}{ 身 長 } & & & \multicolumn{3}{|c|}{ 体 重 } \\
\hline & & $\mathrm{N}$ & $\mathrm{M} \pm \mathrm{SE}$ & & & $\mathrm{N}$ & $\mathrm{M} \pm \mathrm{SE}$ & \\
\hline \multirow[t]{4}{*}{1} & 系球体疾患 & 57 & $-1.25 \pm 0.24$ & 7 & & 58 & $-1.27 \pm 0.15$ & \\
\hline & 一次性系球体腎炎 & 33 & $-1.35 \pm 0.32$ & & & 33 & $-1.48 \pm 0.19$ & * \\
\hline & ネフローゼ症候群 & 18 & $-1.26 \pm 0.46$ & 7 & & 17 & $-1.11 \pm 0.26$ & * \\
\hline & 二次性系球体腎炎 & 6 & $-0.63 \pm 0.46$ & & $*$ & 8 & $-0.72 \pm 0.40$ & \\
\hline 2 & 慢性腎孟腎炎 & 5 & $-2.13 \pm 0.49$ & * & $*$ & 5 & $-1.93 \pm 0.17-$ & \\
\hline 3 & 代謝性腎疾患 & 1 & -7.87 & $*$ & & 1 & -3.78 & \\
\hline 4 & 先天性腎尿路奇形 & 17 & $-2.58 \pm 0.50$ & - & & 18 & $-1.58 \pm 0.29$ & \\
\hline 5 & アルポート症候群 & 7 & $-1.72 \pm 0.38$ & & & 8 & $-1.81 \pm 0.34$ & \\
\hline 6 & その他 & 2 & $-0.21 \pm 0.67$ & & & 2 & $0.72 \pm 0.21$ & \\
\hline \multirow[t]{2}{*}{7} & 不 明 & 2 & $-1.15 \pm 0.68$ & & & 2 & $-0.22 \pm 0.30$ & \\
\hline & 計 & 91 & $-1.63 \pm 0.19$ & & & 94 & $-1.37 \pm 0.12$ & \\
\hline
\end{tabular}

(2.6\%)，体重で2例 (5.1\%) であった.

39 例の身長の $Z$ スコア (mean土SE) は $-0.60 \pm$ 0.26 , 体重のそれは一 $0.46 \pm 0.18$ で, 疾患別には, 先天 性腎尿路奇形の身長は $-1.97 \pm 0.50$ と最も低く, 一次性 系球体疾患 $(-0.05 \pm 0.20)$ との間に有意差が認められ た $(\mathrm{p}<0.01)$ 。また, 糖原病と原疾患不明の各 1 例に高 度の発育障害を認めた (表 3 ).

4. 透析導入時の発育とZスコア

91 例中, 身長が -2 SD 以下のものは 30 例 (33.0\%), 体重では 24 例 $(26.4 \%), 2 \mathrm{SD}$ 以上のものは身長・体重 ともに無かった。

91 例の身長の $Z$ スコア (mean $\pm \mathrm{SE})$ は $-1.63 \pm$ $0.19,94$ 例の体重のそれは-1.37 0.12 で, 身長・体重 ともに発症/発見時より有意に低下し $(\mathrm{p}<0.01, \mathrm{p}<$ $0.001)$, 先天性腎尿路奇形群 $(-2.58 \pm 0.50)$ は系球体 疾患群 $(-1.25 \pm 0.24)$ ・ネフロゼ症候群 $(-1.26 \pm$
$0.46)$ 二次性系球体腎炎 $(-0.72 \pm 0.40)$ との間に有意 差を認めた（各 $\mathrm{p}<0.05, \mathrm{p}<0.05, \mathrm{p}<0.01$ ). また, 慢性腎孟腎炎の体重は $-1.93 \pm 0.17$ で, 系球体疾患群 $(-1.27 \pm 0.15)$ との間に有意差があった（ $\mathrm{p}<0.05)$. 糖原病の 1 例は, 身長 -7.87 , 体重 -3.78 と著明な低下 を示した (表 4 ).

5. 最終観察時の発育とZスコア

87 例中, 身長が -2 SD 以下のものは 41 例 (47.1\%), 体重では 32 例 $(36.8 \%), 2 \mathrm{SD}$ 以上のものは身長・体重 ともに無かった。

87 例の身長の $Z$ スコア (mean $\pm \mathrm{SE})$ は $-2.16 \pm$ $0.21,90$ 例の体重のそれはー $1.73 \pm 0.11$ で, 導入時に比 しさらに低下する傾向（ $\mathrm{p}<0.10, \mathrm{p}<0.20)$ があり， 疾患別には, 先天性腎尿路奇形の身長は $-2.77 \pm 0.45$ で,二次性系球体腎炎との間に有意差が認められた $(\mathrm{p}<$ $0.05)$ 。また，原疾患不明の 4 例 $(-3.17 \pm 0.49)$ と糖原 
表 5 最終観察時の身長および体重 Zスコア

\begin{tabular}{|c|c|c|c|c|c|}
\hline & \multirow{2}{*}{ 原疾患群 } & \multicolumn{2}{|r|}{ 身 長 } & \multicolumn{2}{|r|}{ 体 重 } \\
\hline & & $\mathrm{N}$ & $\mathrm{M} \pm \mathrm{SE}$ & $\mathrm{N}$ & $\mathrm{M} \pm \mathrm{SE}$ \\
\hline \multirow[t]{4}{*}{1} & 系球体疾患 & 51 & $-1.83 \pm 0.27$ & 52 & $2-1.60 \pm 0.14$ \\
\hline & 一次性系球体腎炎 & 26 & $-2.18 \pm 0.43$ & 27 & $7-1.69 \pm 0.22$ \\
\hline & ネフローゼ症候群 & 17 & $-1.73 \pm 0.38$ & 17 & $7-1.64 \pm 0.21$ \\
\hline & 二次性系球体腎炎 & 8 & $-0.95 \pm 0.47$ & & $8-1.20 \pm 0.23$ \\
\hline 2 & 慢性腎孟腎炎 & 4 & $-2.40 \pm 0.68$ & * & $5-2.40 \pm 0.37$ \\
\hline 3 & 代謝性腎疾患 & 1 & -8.16 & & $1-3.98$ \\
\hline 4 & 先天性腎尿路奇形 & 19 & $-2.77 \pm 0.45$ & 19 & $9-1.75 \pm 0.28$ \\
\hline 5 & アルポート症候群 & 5 & $-1.85 \pm 0.46$ & & $6-1.63 \pm 0.38$ \\
\hline 6 & その他 ～～～～～ & 3 & $-0.57 \pm 0.45$ & & $3-1.36 \pm 0.32$ \\
\hline \multirow[t]{2}{*}{7} & 不 明 & 4 & $-3.17 \pm 0.49$ & & $4-2.31 \pm 0.63$ \\
\hline & 計 & 87 & $-2.16 \pm 0.21$ & 90 & $0-1.73 \pm 0.11$ \\
\hline
\end{tabular}

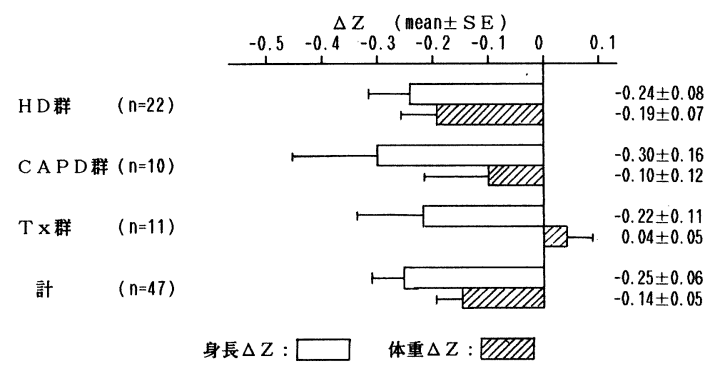

図 2 治療法と $\Delta Z$ ( $Z$ スコア年次変化量)

${ }^{*}: p<0.05$

表 $6 \Delta Z$ 低值例と高值例の検討

\begin{tabular}{|c|c|c|c|c|}
\hline & \multicolumn{2}{|c|}{$\begin{array}{c}\Delta Z<-0.5 \\
\mathrm{n}=11\end{array}$} & \multicolumn{2}{|c|}{$\begin{array}{c}\Delta Z>0 \\
\mathrm{n}=7\end{array}$} \\
\hline \multirow[t]{7}{*}{ 疾 患 名 } & 慢性系球体腎炎 & 2 例 & 慢性系球体腎炎 & 1 例 \\
\hline & IgA 腎症 & 1 & 慢性腎孟腎炎 & 1 \\
\hline & 膜性増殖性腎炎 & 2 & 低形成腎 & 2 \\
\hline & 紫斑病性腎炎 & 1 & oligomega & \\
\hline & NS (FGS) & 3 & \multicolumn{2}{|c|}{ nephronia 1} \\
\hline & NS (MC) & 1 & Alport 症候群 & 1 \\
\hline & 糖原病 & 1 & 不明 & 1 \\
\hline \multirow{7}{*}{$\begin{array}{l}\Delta Z \text { (中央值) } \\
\text { 導入時 } Z \text { (中央値) } \\
\text { 導入時年齢（平均） } \\
\text { 最終観察時年齢（平均) } \\
\text { 治 療 法 }\end{array}$} & \multicolumn{2}{|c|}{$-0.74(0.54 \sim-1.04)$} & \multicolumn{2}{|c|}{$0.39(0.03 \sim 0.88)$} \\
\hline & \multicolumn{2}{|c|}{$-1.2(-0.2 \sim-7.5)$} & \multicolumn{2}{|c|}{$-3.0(-1.5 \sim-5.3)$} \\
\hline & \multicolumn{2}{|c|}{11 歳 2 月 } & \multicolumn{2}{|c|}{12 歳 8 月 } \\
\hline & \multicolumn{2}{|l|}{13 歳 4 月 } & \multicolumn{2}{|l|}{17 歳 1 月 } \\
\hline & HD & 5 例 & HD & 3 例 \\
\hline & $\mathrm{TX}$ & 3 & $\mathrm{TX}$ & 2 \\
\hline & CAPD & 3 & CAPD & 2 \\
\hline
\end{tabular}

NS：ネフローゼ症候群 FGS：巣状系球体硬化症 MC：微小変化群

$\mathrm{HD}$ : 血液透析, TX : 腎移植

病の 1 例 $(-8.16)$ も著明な身長の発育遅延があった (表 5 ).

6. 治療法と $Z$ スコア年次変化量 $(\Delta Z)$

透析導入後 1 年以上経過を観察しえた 47 例について, 治療法により血液透析 (HD) 群・CAPD 群・腎移植 $(\mathrm{TX})$ 群の 3 群に分けて, Z スコアの年次変化量 $(\Delta Z)$ を比較した.身長の $\Delta Z$ は $\operatorname{HD}$ 群 $(\mathrm{n}=26)-0.24 \pm 0.08$, CAPD 群 $(\mathrm{n}=10)-0.30 \pm 0.16$, TX 群 $(\mathrm{n}=11)-$ $0.22 \pm 0.11$, 全体でー0.25 0.06 と各疾患群に差を認め なかった。体重の $\Delta Z$ は $\mathrm{HD}$ 群 $(\mathrm{n}=26)-0.19 \pm 0.07$, CAPD 群 $(\mathrm{n}=10)-0.10 \pm 0.12, \mathrm{TX}$ 群 $(\mathrm{n}=11) 0.04 \pm$ 0.05 , 全体で-0.14 0.05 と TX 群がやや良好なるも有 意差はなかった. 但し, この 3 群の導入時身長 $Z$ スコア

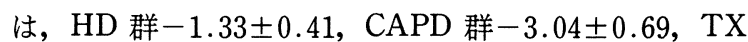

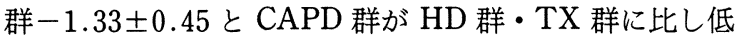
い傾向があり（ $\mathrm{p}<0.05 ， \mathrm{p}<0.10)$, 観察期間 (月) の 中央值も CAPD 群 (17.5) が HD 群 (30.5), TX 群 （41）に比し短かった（図 2 ).

7. 身長 $\Delta Z$ の低值例・高值例

身長の $\Delta Z$ がー 0.5 以下の例は 11 例で, 糖原病の 1 例 を除き全て系球体疾患であり, 導入時 $Z$ スコアは 7 例 がー2 SD 以内にあった. 治療法には一定の傾向は認めな かった. $\Delta Z$ が 0 より大きいのは 7 例で, うち系球体疾患 は 1 例のみで, 慢性腎孟腎炎, 先天性腎尿路奇形, アル ポート症候群など導入時 $Z$ スコアが $-2 \mathrm{SD}$ より低いも のが 5 例と多かった。また，治療法には一定の傾向はな かった（表 6 ). 


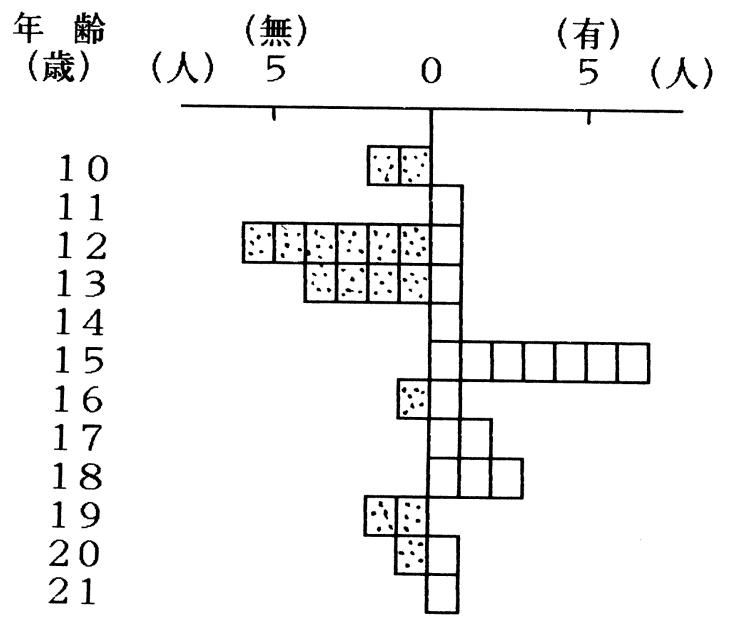

図 3 末期腎不全女児における最終観察時年 歯と月経の有無

\section{8. 初潮について}

月経の有無について回答のあった 37 例中, 15 歳以上 のものは 19 例で, うち 4 例 (21.1\%) で月経が発来して いなかった。そのうち 3 例は最終観察時年齢が 19 から 20 歳にあり, 慢性腎炎・FGS・慢性腎孟腎炎で, 最終 Z スコアが $-3 \mathrm{SD}$ 以下であった（図 3 ).

\section{考案}

小児期慢性腎不全患者においては，36〜 68\%に成長発 育障害が認められる ${ }^{1)}$ と報告されており，この問題の解 決は患者の健全な self body image を培い, 社会復帰へ の精神的・肉体的 handicap を取除く意味で重要と思わ れる。

今回の調査によれば，身長が -2 SD 以下の患児は， 発症/発見時で $17.9 \%$, 透析導入時で $33.0 \%$, 最終観察 時で $47.1 \%$ と経過を追うにしたがって増加する傾向が みられ， Zスコアも発症/発見時 $-0.60 \pm 0.26$ (mean土 $\mathrm{SE})$, 透析導入時 $-1.63 \pm 0.19$, 最終観察時 $-2.16 \pm 0.21$ と低下した。一方，体重についても $-2 \mathrm{SD}$ 以下の患児 が発症/発見時で $12.8 \%$, 透析導入時で $26.4 \%$, 最終観 察時で $36.8 \%$ と増加し，Zスコアも発症/発見時一 $0.46 \pm 0.18$, 透析導入時 $-1.37 \pm 0.12$, 最終観察時一 $1.73 \pm 0.11$ と低下した。このことは，一般に慢性腎不全 児の成長発育は, 保存療法中も透析/移植導入後も経過を 追って正常児との較差が増大することを示している.

腎不全時の成長発育障害の原因としては，尿毒性物質 の蓄積, $\mathrm{Ca} \cdot \mathrm{P}$ 代謝障害に基づく骨病変, 内分泌学的異 常, 糖・蛋白・脂質代謝異常を含めた栄養障害, 貧血, アシドーシスなど多くがあげられるが，腎不全の原疾患 の種類や発症様式，合併症などにより成長発育障害の程
度も異なる．今回の検討では，先天性腎尿路奇形例と糖 原病例で発見時から著しい遅延を認め, これは, 乳幼児 期における最も発育の盛んな時期から持続する腎機能障 害と他の合併した障害に起因すると思われる。また，慢 性腎孟腎炎例も透析導入時に発育遅延傾向がみられ，腎 不全状態の期間の長さや尿細管障害が影響すると思われ る.したがって, 先天性疾患群・慢性腎盂腎炎群では乳 幼児期における早期発見・早期治療管理が不可欠であろ う.

末期腎不全期の治療法による発育状況の差異について は, CAPD 例で HD 例より良い結果を得ているとの報 告 ${ }^{2,3)}$ がある。腎移植例での報告では, 移植後には移植時 点よりさらに遅延傾向が増強するとするもの ${ }^{1,4,5)}$ や, $\mathrm{CAPD}$ と同程度であるとするもの ${ }^{2)}$, 移植 1 年以降約 6 割が正常の発育速度を示したとするもの ${ }^{6)}$, 乳児例での 良好な結果 ${ }^{7)}$ な゙様々である. CAPDの HD に対する優 位性の理由としては, 食事制限の緩和によるカロリー捸 取の増加, アシドーシスの改善, ROD の軽快などがあげ られ, 移植のそれとしては, 腎機能の回復, 新しい免疫 抑制剂による生着率の改善とステロイド節減効果があげ られる。 今回の retrospective な検討では, CAPD 群・ 移植群の HD 群に対する優位性は認められず, 三者とも ほぼ同程度であった。ただし，現在までの治療法に選択 においては，HDを行いがたい低体重児に CAPD が多 用され，腎移植移行例は比較的全身状態の良い症例であ るなどの事実があり, 今回の対象も CAPD 導入症例の身 長 $Z$ スコアが有意に低值であることが三者の公正な比較 を困難にしている。いまだ CAPD の症例数が少なく, 観 察期間も短期間であることからも, 今後継続した検討が 必要である。

透析導入以降の発育が改善を示す $(\Delta Z>0)$ 例と著し く増悪を示す $(\Delta Z<-0.5)$ 例について検討した結果て は, 改善を示すものは導入時の発育障害が著しく，増覀 を示すものは軽度であることがわかり, 発育程度が治療 法による影響とは考えられなかった。したがって，著し い発育障害を有する腎不全児では，早期に透析導入した ほうが発育には有利と考えられるが, $-2 \mathrm{SD}$ 以下か ら $-2 \mathrm{SD}$ 以内に入ってくるものはむしろ例外的であ り，多くは期待できない.

性的発育の指標として, 月経の有無を調査したところ, 15 歳以上の 19 例中 4 例で初潮がみられなかった。腎不 全例で初潮の平均年齢が 15.3 歳との報告 ${ }^{6}$ もあり, 一般 に遅延傾向があるとされている。 4 例中 3 例は最終観察 時 $Z$ スコアが $-3 \mathrm{SD}$ 以下の高度発育障害例であり，身 体発育遅延例では性的発育の遅延も伴うことが示唆され た。 


\section{結論}

国立療養所 21 施設を対象として, 小児期末期腎不全患 者の成長発育についてアンケート調査を行い, 以下の結 論を得た。

1.これまでに経験した症例は 118 例で，1987 年 8 月 現在 2 例が透析導入前, 61 例が透析により生存, 22 例が 腎移植により生存, 17 例が死亡, 16 例は不明である。

2 . 発症/発見時の $Z$ スコアは身長 $-0.60 \pm 0.26$ （39 例), 体重 $-0.46 \pm 0.18$ (39 例) で, 先天性腎尿路奇形で 低い傾向があった。

3. 透析導入時の $Z$ スコアは，身長 $-1.63 \pm 0.19$ (91 例), 体重 $-1.37 \pm 0.12$ (94 例) で, 先天性腎尿路奇形・ 慢性腎盂腎炎で低い傾向があった。

4. 最終観察時の Zスコアは，身長 $-2.16 \pm 0.21(87$ 例), 体重 $-1.73 \pm 0.11$ (90 例) で, 先天性腎尿路奇形・ 慢性腎盂腎炎・一次性系球体腎炎で低い傾向があった。

5. 導入後の治療法と発育との間に関係は見られず, ぞの治療法でもZスコアは悪化する傾向にあったが，今 後の検討を要する.

6. 導入後の発育が導入前に比し改善する例は導入時 $Z$ スコアが著しく低いものが多く，著しく悪化する例は 導入時 $Z$ スコアが正常に近いものが多かった。

7.15 歳以上の女览 19 例中 4 例に初潮がみられず, 身 体発育高度遅延例が多かった。

稿を終わるにあたり，アンケート調査に御協力いただきま した全国療養所の諸先生方に心から深謝いたします。 なお,この論文の要旨は第 31 回日本腎臓学会総会において
発表された。

\section{文献}

1) Potter DE, Greifer I : Statual growth of children with renal disease, Kidney Int $14: 334-339,1978$

2) Fennel III RS, Orak JK, Hudson T, Garin EH, Iravani A, Van Deusen WJ, Howard R, Pfaff WW, Walker III D, Richard GA : Growth in children with various therapies for end-stage renal failure. Am J Dis Child 138 : 28-31, 1984

3) Yoshioka $T$, Iitaka $K$, Sakai $T$ : Growth velocity and nutritional status in young children undergoing continuous ambulatory peritoneal dialysis : 北 里医学 $16: 7-13,1986$

4）吉田義幸，酒井 紏，吉岡俊正，飯高喜久雄，河西 紀昭, 系満憲盛: 腎移植後の骨病変の変化と成長. 腎と透析 $18 ： 631-636 ， 1985$

5）上山泰淳, 本田雅敬, 長谷川理 : 小児腎移植後の成 長(第 22 回日本移植学会総会)。移植 $21: 170,1986$

6) R van Diemen-Steenvoorde, Donckerwolcke RA, Brackel H, Wolff ED, de Jang MCJW : Growth and sexual maturation in children after kidney transplantation. J Pediatr 110 : 351-356, 1987

7) So SKS, Chang P-N, Najarian JS, Mauer M, Simmonds RL, Nevins TE : Growth and development in infants after renal transplantation. J Pediatr 110 : 343-350, 1987 